\title{
Visszatérő migráció Albániába - ahogy a fiatalok és a gyerekek megélik ${ }^{1}$
}

\author{
LONCSÁK NOÉMI²
}

Az emberek térbeli mozgásának hátterében számos tényező állhat, Illés (2001) szerint a vándorlások általában a külső körülmények által befolyásolt szabad egyéni és néha csoportos akarat eredményei, melyekre a makroszintű folyamatok mellett az egyéni életút egyes fázisváltozásai is hatnak. A szakirodalom alapján Lados (2018) összegyüjtötte, hogy a migrációs döntések min alapulhatnak, ez alapján beszélhetünk egyéni tényezőkről (pl. tanulmányi célú mozgás), természeti tényezőkről (pl. árvizek), gazdasági okokról vagy politikai tényezőkről (pl. háborúk). A dolgozatban a migrációs döntések meghozatalának hátterében kiemelt szerepe van az egyéni szempontoknak, a családnak, a gyerekek jövőjének, valamint a gazdasági-társadalmi tényezőknek, mivel vándorlásukat a gazdasági válság idézte elő. Ugyanakkor a gyerekek valójában nem döntenek maradásukról vagy migrációjukról, még ha a háttérben szem elött is tartja érdekeiket a család.

A közelmúltbeli gazdasági válságot követően számos országban társadalmi és politikai zűrzavar volt tapasztalható, aminek következtében sokan, többek között albán migránsok is úgy vélték, hogy a bizonytalanság idején a legjobb megoldás a hazájukba való visszatérés. A visszatérő migrációra vonatkozó szakirodalom áttekintése mellett ez a kutatás a migránsok egy olyan csoportját vizsgálja, akiket korábban nem vizsgáltak széles körben. A kutatás feltárja a hazatérő bevándorlók és gyermekeik Albániában szerzett tapasztalatait, összpontosítva azokra a településekre, amelyekre hazatértek, a hozzátartozás érzésének újbóli megépítésének módjaira és arra, hogy ezek a változások hogyan befolyásolják identitásukat. A kutatás unikális jellege abban rejlik, hogy egyszerre vizsgálja a visszatérő migrációban érintett szülőket és gyerekeiket.

Az albán migráció, amely már a rendszerváltás idején is hatalmas mértékű volt, és nagymértékben hatott magára a rendszerváltásra is ${ }^{3}$, felkeltette a nemzetközi társadalomtudományok gondolkodóinak érdeklődését. Számos PhD dolgozat is szüle-

\footnotetext{
${ }^{1}$ Cena, E. (2017): Return migration during the economic crisis: Experiences of Albanian return migrants and their children in the quest to belong (Doctoral dissertation, Edge Hill University).

${ }^{2}$ Doktorandusz, Debreceni Egyetem Szociológia Társadalompolitika Doktori Program.

${ }^{3}$ Lásd erről: King, R. - Vullnetari, J. (2003): Migration and development in Albania. http://www. sussex.ac.uk/Units/SCMR/drc/publications/working_papers/WP-C5.pdf
} 


\section{OLVASS FELESLEGESET!}

tett a témában, sőt a Baganha-díjat két évben is (2010,2012) az albán migrációval foglalkozó doktori disszertáció nyerte el, melyek közül az egyik fókuszában - jelen dolgozathoz hasonlóan - a gyerekek álltak. ${ }^{4}$

\section{A módszerről}

A kutatás módszertani erőssége a kvalitatív technikák sokszínű alkalmazásában rejlik, a szerző használt a megszokott interjúkon, fókuszcsoportokon felül családi esetleírásokat, résztvevő megfigyelést, rajzelemzést és az interjúk felvételekor segítségül hívott fénykép elemzést is. Külön figyelmet fordított az alanyok életkorára, ehhez igazította a kutatási dizájnt. A felnőtteknél és a tinédzsereknél (13-18 évesek) használt interjúkat, fókuszcsoportos kérdezéseket és az általuk elmondottak alapján készültek el a családi esetleírások, valamint a beszélgetése előtt kért tőlük fényképeket mindkét országból és ezek bemutatására is felkérte az alanyokat. Míg a fiatalabb gyerekeket elsősorban rajzolással vizsgálta, ami kiegészítette a családok leírását, közös élményeiket, tapasztalataikat.

Két hullámban történt az adatfelvétel, ezzel alapjaiban egy longitudinális vizsgálatra törekedett a szerző. Az első adatgyűjtés 2015 májusában és júliusában történt, míg a nyomon követési adatgyưjtés (második hullám) egy év elteltével 2016. május-júniusban. Két település került kiválasztásra a kutatás helyszínéül, Tirana és Fier. Kiválasztásukat a visszatérő migránsok magas aránya indokolta, valamint mindkét település képvisel egy-egy típust, mint a főváros és mint egy vidéki város Albániában. A kutatás fő célja, hogy megértse a gazdasági válság miatt visszatérő bevándorlók tapasztalatait, így a kiválasztott alanyok többsége elsősorban Görögországból vagy Olaszországból tért haza.

Mivel az alanyok több mint fele iskoláskorú gyerek, ezért a terepmunka fó helyszíneit az iskolák jelentették, valamint a kutató megfigyelései alapján a toborzás és a lekérdezés másik helyszínei az ortodox egyház intézményei voltak, mivel a viszszatérő migránsok és gyerekeik nagy százalékban látogattak egyházi programokat.

A mintába került gyerekek esetében fontos figyelembe venni, hogy szinte mindegyikőjük a másik országban látta meg a napvilágot, tehát számukra szüleik visszatérő migrációja nem egyértelműen jelöl valódi visszatérést, hiszen ők sosem éltek Albániában, „visszatérési” tapasztalataik ezáltal atipikusnak mondható.

${ }^{4}$ Vathi, Z. (2011): The children of Albanian migrants in Europe: ethnic identity, transnational ties and pathways of integration. Doctoral thesis, University of Sussex. http://sro.sussex.ac.uk/id/eprint/7421/ 


\section{OLVASS FELESLEGESET!}

\section{A visszatérő migráció jelensége}

Ezen fejezetcím alatt az elméleti megközelítéseket és a korábbi kutatások eredményeit foglalja össze a szerző. A visszatérő migrációra Markowitz és Stefansson (2004) alapján egy kihívást jelentő folyamatként tekint, mint egy újbóli beilleszkedésre az adott társadalomba. A visszatérő migráció a vándorlás egy különleges válfaja abban a tekintetben, hogy a módosult körülmények között az elvándorolt személy számára van menekülési útvonal, amely esetükben a származási országot jelenti. Ahogyan arra az idézett elméletek is utaltak, a szerző érdekelt a visszatérés ösztönzőinek feltárásában, a visszatérés kontextusában és körülményeiben, valamint abban, hogy ez egyfajta a válság hatására létrejött kényszerhelyzet, amely másféle értelmezést követel. A vándorlást előmozdító taszító (push) és vonzó (pull) tényezők közül ebben a megváltozott gazdasági társadalmi környezetben feltehetően jóval több a taszító elem a korábban vonzónak tartott országban. A származási ország, esetünkben Albánia vonzó ereje valószínúleg nem változott olyan mértékben, hogy a korábban elvándorolt családok potenciált lássanak benne, sokkal inkább Görögország és Olaszország megváltozott, taszító tényezői képezhetik a visszatérő migráció okát.

Korábbi kutatások (Dustmann 2003, Konzett-Smoliner 2016) megállapították, hogy a visszatérő migráció elsődleges oka valamilyen családi megfontolás. A közelmúltig a migrációs tanulmányok a gyermekekkel kapcsolatban azon az állásponton voltak, hogy a migrációban a gyerekek „poggyászként” vagy a felnőttek szorongásának és terheinek forrásaként vannak jelen (Dobson 2009). A gyerekekhez való közelítése a dolgozatnak elsősorban az, hogy milyen mértékben vesznek részt a családi migrációs döntéshozatali folyamatban maguk a gyerekek, mennyire befolyásolják a család maradását vagy visszatérését a gyermekek lehetőségei és igényei.

Albánia azért is érdekes választás a szerző részéről, mivel ebben az országban kialakult egyfajta trend a visszatérésre, 2008-tól kezdődően folyamatosan nőtt azoknak a száma, akik megpróbáltak másik országban élni, azonban valamilyen okból kifolyólag hazatértek. A visszatérés megkönnyítése érdekében az albán kormány külön szakpolitikai intézkedéseket indított „Visszatérő bevándorlók újbóli beilleszkedésének nemzeti stratégiája 2010-15" néven. Mindezt egyfajta fenntartható visszatérés reményében, hogy támogassa az önkéntesen és akaratlanul mozgó emberek visszafogadási és reintegrációs folyamatát.

\section{A dolgozat eredményei}

Ahogyan a szerző korosztályok szerint differenciált a módszer kiválasztásánál, úgy tette azt az eredmények bemutatása során is. Három csoportot különböztetett meg, melyeket felnőtt, tinédzser és gyerek kategóriaként definiált, ezzel szerette volna az eltérő migrációs tapasztalatokat, identitásválságokat életkor szerint feltárni és megkülönböztetni. 


\section{OLVASS FELESLEGESET!}

A felnőttekről szóló fejezet a visszatérési migrációval kapcsolatos tapasztalataikat, foglalkoztatási lehetőségeiket vizsgálta, külön kitért a hazájukkal való azonosulás szintjére, a társadalmi kapcsolataikra és a jövőbeni utakra, terveikre. Ezek alapján az látszik, hogy az Albániában tapasztalható lehetőségek hiánya miatt az energiákat a jövőbeni migrációs mobilitások keresésének módjaira irányítják, ezzel mintegy kialakítva egy körkörös migrációt, melyben úgy tűnik a hazatérés egy menekülési útvonalat jelent az aktuálisan rossz helyzetből. A gazdasági válság hatására bekövetkezett visszatérő migráció egy egészen ambivalens helyzet, melyben a hazatérés egyfajta „hazatérő szörnyűség”-ként értelmezhető. A visszatérési tapasztalatok nemek szerint különböznek, a korábban dolgozó nőknek Albániába való hazatérésükkel együtt hagyományosabb szerepeket és értékeket kellett elfogadniuk. A nők sebezhetőbbek a migrációs folyamatban, mert munkaképes korban munkanélküliséget és gyakran pszichológiai problémákat tapasztaltak, míg a férfiak rugalmasabban közelítették meg a visszatérést, könnyebben tudtak barátokhoz fordulni támogatásért, és úgy tűnik, hogy szélesebb foglalkoztatási lehetőségük van. A nyomon követési hullám alapján az egy éven belül mért változások nem jelentősek, mivel a gazdasági lehetőségek nagyobb mértékben nem változnak ez idő alatt, öszszehasonlító kutatásra lenne szükség ahhoz, hogy jobban meg lehessen állapítani a különbségeket több év elteltével, erre már a szerző is utal.

A tinédzserek számára a szülők származási országába való visszatérés alapvetően egy nehéz időszak. A visszatérő tizenévesek kihívásokkal szembesülnek az iskolai teljesítményben, a társadalmi kapcsolataikban és a családjukon belül is. Akcentusuk, viselkedésük és megjelenésük miatt stigmatizációval találkoznak kortárscsoportjaikban, ami társadalmi kirekesztéssé nőheti ki magát, különösen a visszatérés kezdeti szakaszaiban. Fontos a tinédzserek kapcsán a földrajzi elhelyezkedés, ami azt mutatja, hogy a tizenévesek Fiernél több nehézséggel találkoznak, mint a tizenévesek Tiranában, ami a szerző megállapítása alapján azt jelzi, hogy a normatív szociális elvárások szigorúbbak Fier-ben. A szülők a visszatérés után kevésbé támogató szerepet töltenek be a tinédzserek életében. Pontosabban, a szülők egyre nagyobb mértékben kontrollálják a tinédzser gyermekeiket, amikor Albániába visszatérnek, szigorúbb szabályokat gyakorolnak és akadályozzák gyerekeiket abban, hogy élvezhessék korábbi szabadságukat. A család szerepe, a szülő-gyermek viszony, döntő fontosságú az adaptációs folyamatban, a tinédzserek számára ugyanakkor fontos szerepet töltenek be a különböző szervezetek által végzett beilleszkedést segítő programok. A kutatás a tinédzserek kapcsán arra világít rá, hogy számukra a hozzátartozás érzését leginkább olyan helyek és gyakorlatok megszervezésével lehet kialakítani, amelyek az előző országhoz kapcsolják őket, ezzel pedig mintegy hidat képeznek számukra az Albániával való kapcsolataikban is.

A gyerekek élményeinek, tapasztalatainak feldolgozását az általuk készített rajzok segítették, rávilágítottak arra, hogy a mindennapi helyek és a társadalmi kap- 


\section{OLVASS FELESLEGESET!}

csolatok fontosak számukra, és hogy ezek a szerzett élmények befolyásolják az „új” élethez való alkalmazkodásuk sikerét. A visszatérő bevándorlók gyermekeikkel való kapcsolata a múlt és a jelen helyek közötti tárgyalásokat vonja maga után, ezek közös átbeszélése, különbségek feltárása befolyásolja a gyerekek identitásépítésének folyamatát. A tinédzserekkel ellentétben a szülőknek kiegyensúlyozottabb szerepük van a fiatalabb gyermekek visszatérésében, támogatják és elősegítik a reszocializációs folyamatokat, amelyek pozitívan befolyásolják a gyermekeket.

\section{Összefoglalóan...,}

az eredmények összességében arra utaltak, hogy a gazdasági válság idején a visszatérő migráció mélyen befolyásolta a családi struktúrát és a családi élet általános minőségét. Különösen a jelenlegi kutatásban részt vevő alacsonyabb jövedelmű családok esetében a „kényszerű visszatérés”, a munkakörülmények és a gazdasági nehézségek gyakran a családi konfliktusokhoz vezettek. Lehetne azt mondani, hogy nincs új a nap alatt, azonban a dolgozatban kidolgozott elméleti háttér és a frappáns módszertani megközelítés megér egy olvasást, még ha helyenként nem is lettek kielégítően feldolgozva az összegyűjtött információk.

\section{Irodalom}

Dobson, M. E. (2009): Unpacking children in migration research. Children's Geographies, 7(3), 355-360.

Dustmann, C. (2003): Children and return migration. Journal of Population Economics, 16(4), 815-830.

Illés S. (2001): A belföldi vándormozgalom alakulása és népesedési összefüggései. In: Cseh-Szombathy L. - Tóth P. P. (szerk.): Népesedés és népességpolitika. Budapest, Századvég. 363-394.

Konzett-Smoliner, S. (2016): Return migration as a 'family project': exploring the relationship between family life and the readjustment experiences of highly skilled Austrians. Journal of Ethnic and Migration Studies, 42(7), 1094-1114.

Lados G. (2018): A Magyarországra történő visszavándorlás társadalomföldrajzi vizsgálata. Doktori (PhD-) értekezés, Szeged.

Markowitz, F. - Stefansson, A. H. (2004): Homecomings: Unsettling Paths of Return. Oxford, Lexington Books. 